\title{
Seaweeds as Biomonitoring System for Heavy Metal (HM) Accumulation and Contamination of Our Oceans
}

\author{
Vincent van Ginneken*, Evert de Vries \\ Bluegreen Technologies, Heelsum, The Netherlands \\ Email: *vvanginneken@hotmail.com
}

How to cite this paper: van Ginneken, V. and de Vries, E. (2018) Seaweeds as Biomonitoring System for Heavy Metal (HM) Accumulation and Contamination of Our Oceans. American Journal of Plant Sciences, 9, 1514-1530.

https://doi.org/10.4236/ajps.2018.97111

Received: March 5, 2018

Accepted: June 23, 2018

Published: June 26, 2018

Copyright $\odot 2018$ by authors and Scientific Research Publishing Inc. This work is licensed under the Creative Commons Attribution International License (CC BY 4.0).

http://creativecommons.org/licenses/by/4.0/ (c) (i) Open Access

\begin{abstract}
This research manuscript reports the heavy metal accumulation in four marine seaweeds sp. 1) Caulerpa sertlatioides (Cuba); 2) Caulerpa cf. brachypus; (Bali, Indonesia); 3) Undaria pinnatifida (West-Donegal, Ireland); 4) Ulva lactuca (Easters-Scheldt, the Netherlands). Mechanical pressure at 10 bar of fresh seaweed fronds casu quo biomass in the laboratory delivered seaweed moisture which was analyzed by Inductively Coupled Plasma Spectroscopy (ICP)-techniques for heavy-metals = $[\mathrm{HM}],(\mathrm{Al}, \mathrm{As}, \mathrm{Cd}, \mathrm{Co}, \mathrm{Cr}, \mathrm{Cu}, \mathrm{Fe}, \mathrm{Mo}$, $\mathrm{Ni}, \mathrm{Pb} \& \mathrm{Zn}$ ). Three important observations were made: 1) The $[\mathrm{HM}]$ in the seaweed moisture is higher than in the surrounding seawater which directs to mechanism(s) of bio-accumulation; 2) The accumulation factor [AF] is varying per metallic-cation with an overall trend for our four seaweeds and sampling locations for $[\mathrm{HM}]$ are: As \& Co \& Cu: 5000 - 10,000 $\mu \mathrm{g} / \mathrm{l}$; Ni \& Zn: 3000

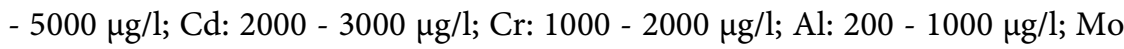
\& $\mathrm{Pb} \&$ Fe: 0 - $200 \mu \mathrm{g} / \mathrm{l}$ range. 3) Seaweed moisture detected that [HM]: $\mathrm{Pb} \&$ $\mathrm{Zn} \& \mathrm{Fe}$-which all three could not be detected in the seawater-supports the view that seaweeds have a preference in their bio-accumulation mechanism for these three HM. Major conclusion is in general that "overall" for the macro-elements $\mathrm{Ca}, \mathrm{Fe}, \mathrm{K}, \mathrm{Mg}, \mathrm{Mn}, \mathrm{Na}, \mathrm{P} \& \mathrm{~S}$ in the moisture of the four seaweed species the concentration is lower in the seaweed species, or equals the concentration, in comparison to the surrounding sea water. For the $\mathrm{HM}(\mathrm{Al}$, As, $\mathrm{Cd}, \mathrm{Co}, \mathrm{Cr}, \mathrm{Cu}, \mathrm{Mo}, \mathrm{Ni}, \mathrm{Pb} \& \mathrm{Zn}$ ) the opposite is the case species and is the concentration "overall" higher in the seaweed species in comparison to the surrounding sea water. Further topics addressed include strategies of irrigation of the Sahara desert with the moisture out of seaweeds under conditions of low anthropogenic influences.
\end{abstract}

\section{Keywords}

Seaweeds, Heavy Metal Accumulation, Ulva lactuca, Caulerpa sertlatioides, 
Caulerpa cf. brachypus, \& Undaria pinnatifida, Inductively Coupled Plasma Spectroscopy (ICP)-Techniques, Al, As, Cd, Co, Cr, Cu, Fe, Mo, Ni, $\mathrm{Pb} \& \mathrm{Zn}$, Bio-Accumulation, Biomonitoring, Upper Tolerance Nutrient Intake Levels (ULs), Irrigation Water

\section{Introduction}

Heavy Metal (HM), often used in this manuscript is a general collective term which applies to the group of metals and metalloids with an atomic density greater than $4 \mathrm{~g} / \mathrm{cm}^{3}$ which have in general a large impact on environment in general and inhabiting organisms (flora and fauna) including at the highest trophic level of the ecosystem, the humans [1]. Although it is a loosely defined term, it is widely recognized and usually applies to the widespread contaminants of terrestrial and freshwater ecosystems. Most HMs are well-known toxic and carcinogenic agents and when discharged into the wastewater represent a serious threat to the human population and the fauna and flora of the receiving water bodies. The Dangerous Substances Directive of the European Union [2] defines dangerous chemicals as those which are toxic, persistent and/or bio-accumulative. As they are elements, they cannot be broken down, therefore HM will persist in the environment. Whether the source of HM is natural or anthropogenic, the concentrations in terrestrial and aquatic organisms are determined by the size of the source and adsorption/precipitation in soils and sediments [3]. The concentration of metal in bioavailable form is not necessarily proportional to the total concentration of the metal. The free ion is generally the most bioavailable form of a metal, and the free ion concentration if often the best indicator of toxicity [1]. Metals exert at upper tolerable nutrient intake levels (ULs) toxic effects if they enter into biochemical reactions in the organism and typical responses are inhibition of growth, suppression of oxygen consumption and impairment of reproduction and tissue repair [4]. Most critical levels ( $\approx$ thresholds) for HM have been developed to protect humans [5], although some have been suggested to protect aquatic organisms [6]. The thresholds for irrigation water-which meet the thresholds of the FAO for the different macro- and micro-elements and nutrients-are defined in the manuscript of [7].

The following Heavy Metals (HM) from the Periodic System (Figure 1) can be considered as dangerous: Class a: hard metals: $\mathrm{Li}, \mathrm{Be}, \mathrm{Na}, \mathrm{Mg}, \mathrm{Al}, \mathrm{K}, \mathrm{Ca}, \mathrm{Sc}, \mathrm{Ti}$ Fe (III), Rb, Sr, Y, Zr, Cs, Ba, Hf, Fr, Ra, La, Ac, Th; Class b: soft metals: Cu (I), $\mathrm{Pd}, \mathrm{Ag}, \mathrm{Cd}, \mathrm{Ir}, \mathrm{Pt}, \mathrm{Au}, \mathrm{Hg}, \mathrm{T} 1, \mathrm{~Pb}$ (II) and Borderline: intermediate metals: $\mathrm{V}$, $\mathrm{Cr}, \mathrm{Mn}, \mathrm{Fe}$ (II), Co, Ni, Cu (II), Zn, Rh, Sn, Pb (IV) (Source: [8]). The terms "hard" and "soft" were used to denote the kinds of acids the metals formed. Hard metals form hard acids. Hard acids are compounds characterized by ionic bonds. These compounds are found mobile in living systems and can be easily displaced or flushed out. Soft metals, on the other hand, form soft acids that have covalent bonds. Soft acids are compounds that are observed immobile and 


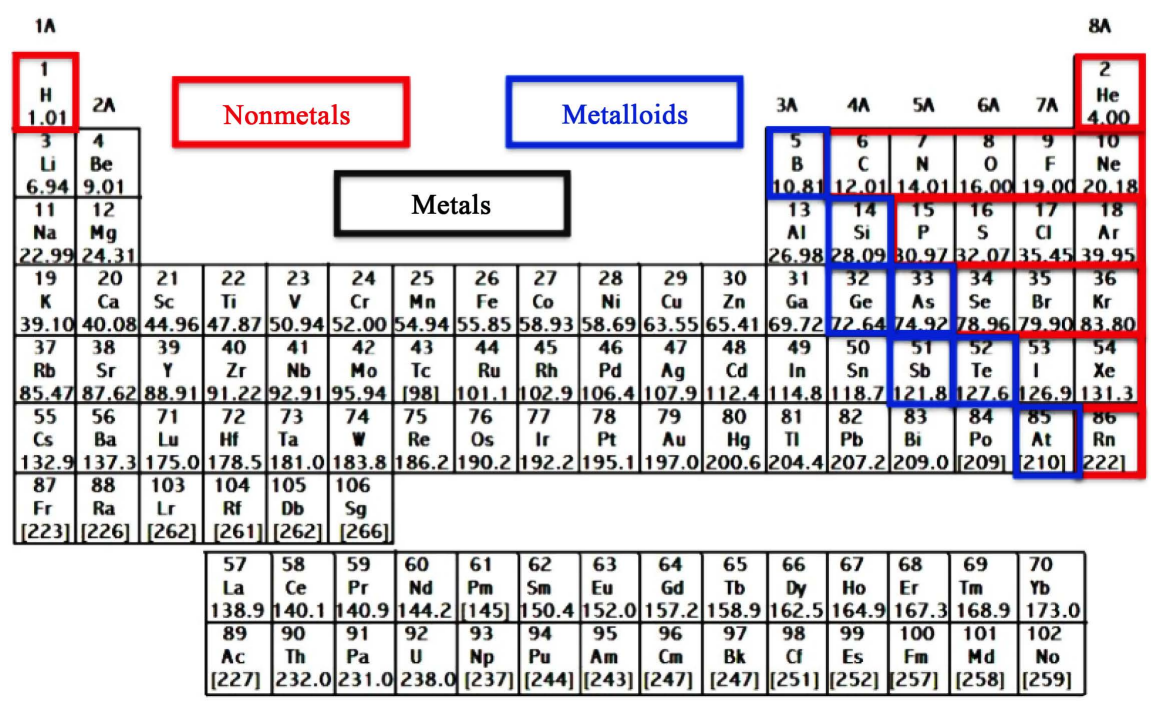

Figure 1. Periodic system with subdivision of nonmetals, metals and metalloids (Source: [8]).

accumulate in living systems with resultant toxicity. The metals included in the "Borderline" category exhibit "Class a" and "Class b" properties. In some cases, a clear distinction between the three different categories cannot be made. Some fall under both categories; like copper may be either "Class b" or "Borderline" depending upon whether it is $\mathrm{Cu}(\mathrm{I})$ or $\mathrm{Cu}(\mathrm{II})$, respectively; lead may be either "Class b" or "Borderline" depending upon whether it is $\mathrm{Pb}$ (II) or $\mathrm{Pb}$ (IV), respectively; and iron may be either "Class a" or "Borderline" depending upon it is $\mathrm{Fe}$ (III) or Fe (II), respectively (reviewed: [8]). This study is the follow-up manuscript of "Irrigation of the Sahara desert with the moisture out of seaweeds: 1) How seaweeds could make Africa the food producing continent of the $21^{\text {st }}$ century"(detailed report in preparation).

We hope to address answers to the following questions:

1) What is the impact of these selected intermediate remote oceanic locations on [HM] concentration in seaweed moisture in comparison to FAO defined [7] HM-thresholds for irrigation water? In other words, is there a correlation between oceanic HM contamination and seaweed moisture [HM]?

2) Because seaweeds are used in field studies as a bio-monitoring system for HM contamination of the oceanic environment [9] [10], does literature supports this optional in the laboratory found correlation?

3) If such a correlation is confirmed by literature data the mechanism of bio-accumulation of HM in the metabolism of the living seaweed at such high concentrations needs to be understood and described (see discussion);

4) After checking the correlation between oceanic HM contamination and [HM] in seaweed moisture: a) the laboratory experiment described in this manuscript; b) literature studies, finally the most important question can be posed: Are the oceanic waters around the Sahara clean enough to form a sound basis for a seaweed industry which in the end can deliver irrigation water with [HM] 
far below the FAO-thresholds for irrigation water? Our initial hypothesis is yes they can!

\section{Material \& Methods}

\subsection{Experimental Set up}

The following materials were used in the experiments.

\subsection{Seaweeds}

- Ulva lactuca (Chlorophyta): =>origin: KatseHeule, Easters-Scheldt, The Netherlands; approximate coordinates: $51^{\circ} 32^{\prime} 30 \mathrm{~N}$ and $3^{\circ} 52^{\prime} \mathrm{E}$ (Figures 2-5).

- Caulerpa sertularioides (Chlorophyta): =>origin: Denpassar, Bali, Indonesia; approximate coordinates: $8^{\circ} 41^{\prime} \mathrm{S}$ and $115^{\circ} 17^{\prime} \mathrm{E}$ (Figure 4 ).

- Caulerpa cf. brachypus (Chlorophyta): =>origin: Cuba): approximate coordinates: $23^{\circ} 50^{\prime} \mathrm{S}$ and $82^{\circ} 50^{\prime} \mathrm{W}$ (Figure 5).

- Undaria pinnatifida, (Wakame) (Phaeophyceae): =>origin, Kilcar, West-Donegal, Ireland, approximate coordinates: $54^{\circ} 37^{\prime} \mathrm{N}$ and $8^{\circ} 37^{\prime} \mathrm{W}$ (Figure 6).

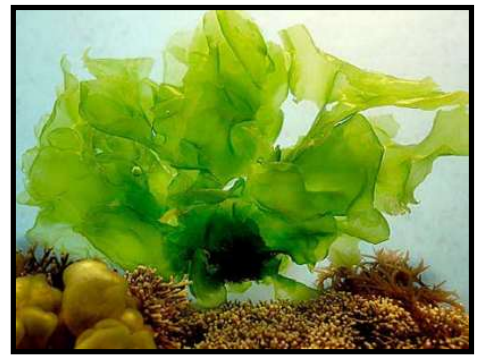

Figure 2. The seaweed Ulva lactuca (Chlorophyta) origin the Netherlands.

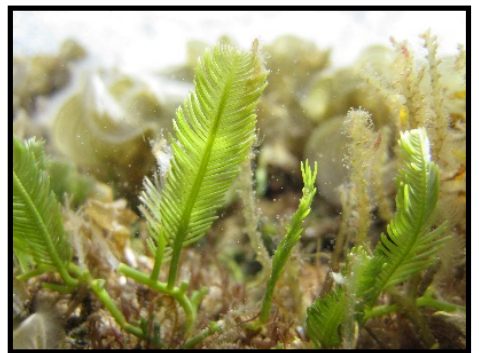

Figure 3. The seaweed Caulerpa sertularioides (Chlorophyta) origin Indonesia.

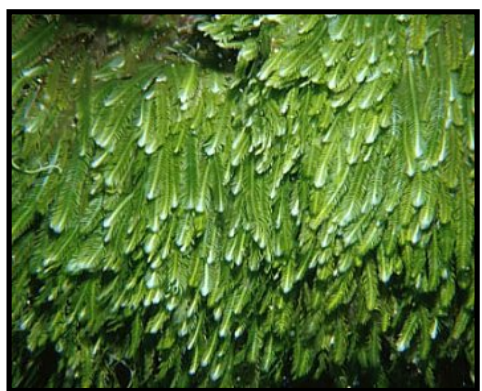

Figure 4. The seaweed Caulerpa cf. brachypus (Chlorophyta). 


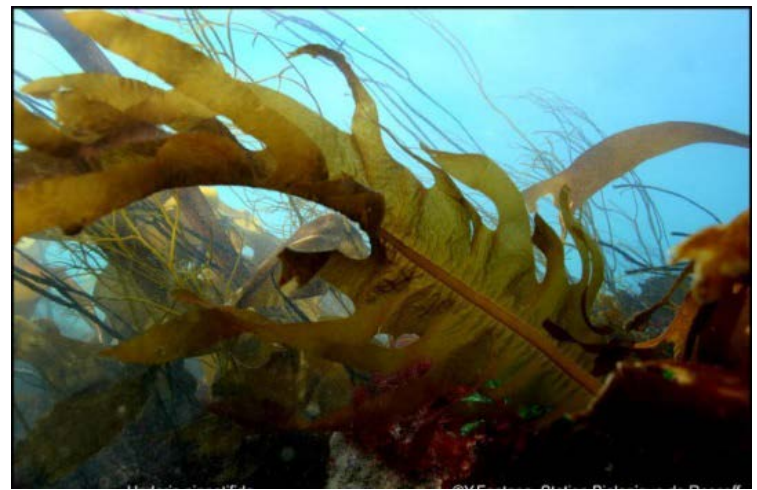

Figure 5. The seaweed Undaria pinnatifida (Phaeophyceae) origin Ireland.

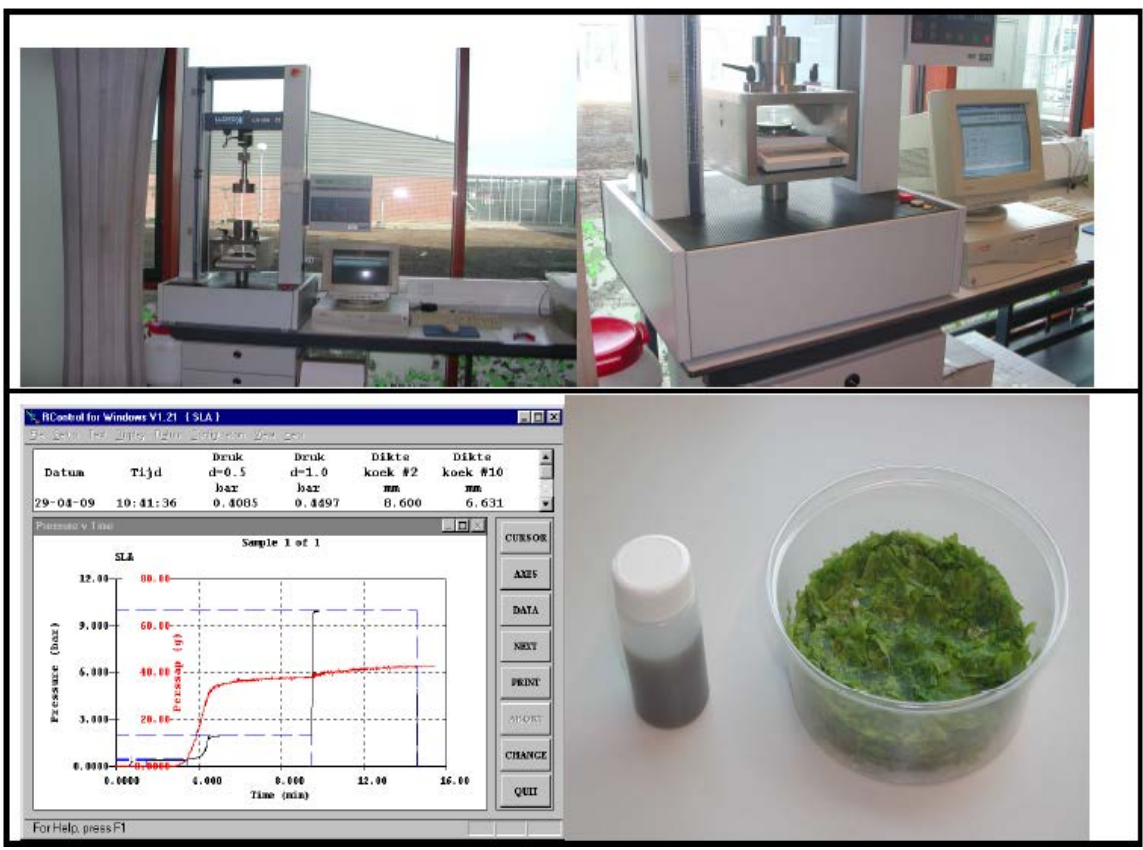

Figure 6. Example of a pressure experiment in the LR30K laboratory press with the seaweed Ulva lactuca.

\subsection{Sampling and Purchasing Seaweeds and Identification Procedures}

Ulva lactuca was collected ourselves and brought directly to the laboratory-together with surrounding water-for species determination with a binocular and microscope according to the criteria of [9]. The other three seaweed species (Caulerpa sertularioides, Caulerpa cf. brachypus, Undaria pinnatifida) were fresh provided by an aquarium wholesaler for seaweed species "De Jong Marinelife", Spijk, (The Netherlands) a purchaser for marine aquariums, with a network of international worldwide contacts. This "aquarium-shop" delivers oceanic sea fishes, corals and seaweeds which are flown together with native surrounding water asp to the shop. Here species were identified by name and by this procedure we obtained rapidly and reliable non-indigenous Netherlands seaweeds which we brought directly to the laboratory for further identification with a bi- 
nocular and microscope according to the laboratory. In addition, we applied the "field manual of Seaweeds" [10] for further species determination. In this experiment we determined for four seaweed species under mechanical pressure until 10 bar pressed moisture weight out of the seaweed fronds for further biochemical analysis. All investigated four seaweeds species gave moisture and with ICP-techniques we investigated it among else for macro- and micro-elements. In addition, in the surrounding oceanic water-at the same time sampled during collection of the seaweeds-with the same ICP-techniques the macro- and micro-elements were determined. This water sample of the surrounding oceanic water directly stored and frozen at $-80^{\circ} \mathrm{C}$ pending analysis.

\subsection{Mechanical Pressure Procedure}

To be able to press juice out of the seaweed biomass the materials were first pulped using a laboratory homogenizer (manufacturer: Foss Tecator, type: Tecator 1094 homogenizer). For seaweed biomass a smooth knife was used, for others a serrated knife was used. For most materials the lower speed of $1500 \mathrm{rpm}$ was sufficient, for other the higher speed of $3000 \mathrm{rpm}$ was needed. Juice was pressed out of the pulp, approximately 100 grams of pulp was used, using a LLOYD INSTRUMENTS (type: LR30K) testing machine that was fitted with a specially constructed unit for pressing pulps at a maximum pressure of $60 \mathrm{bar}$ (see Figure 7: PANEL 1, 2). Pulps were first pressed for 5 minutes at a pressure of 2 bars, after that for another 5 minutes at a pressure of 10 bars (see Figure 7: PANEL 3). Applied pressure, thickness of the press cake and cumulative juice production (see Figure 7: PANEL 4), were continuously monitored. Total weight of press cake and press juice were determined. Afterwards press cake and samples of the obtained seaweed moisture of the four different seaweed species ( $\mathrm{n}=4$ per seaweed species) were immediately stored at $-80^{\circ} \mathrm{C}$ pending analyses.

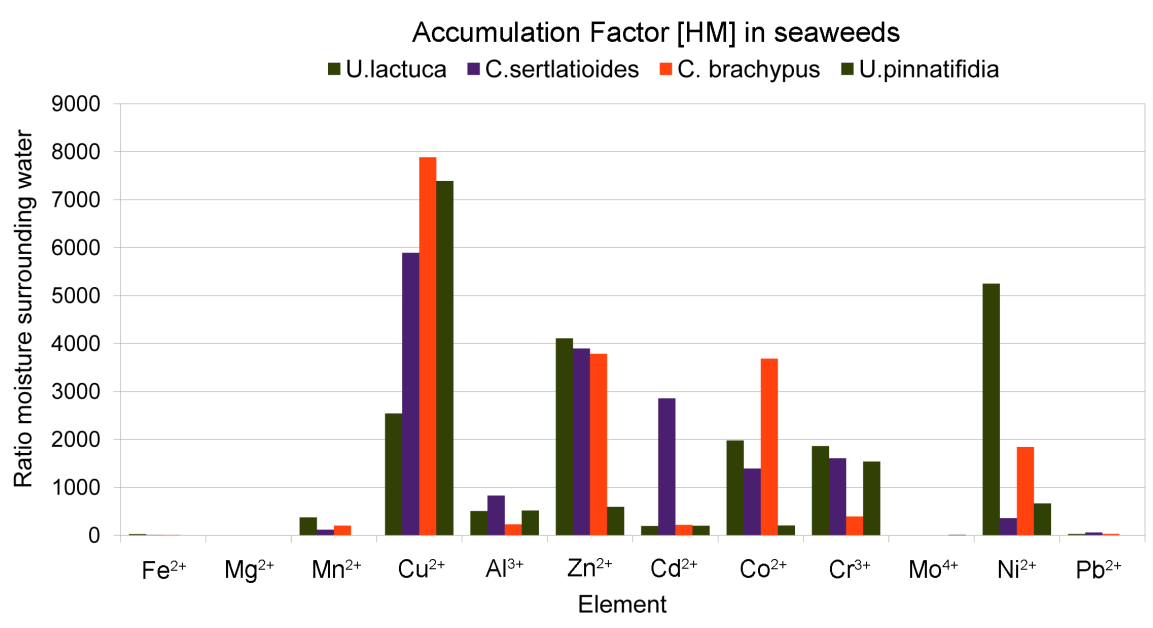

Figure 7. Accumulation factor calculated by the means $(\mathrm{n}=4)$ of HM ion-concentration in the moisture of four different seaweeds divided by the concentration of that metallic cation in the surrounding seawater at the sampling location of that specific seaweed. *: denotes $<$ zero so the threshold value of the ICP-MS method is chosen as denominator. 


\subsection{Determination of Micro- and Macro-Elements (Including HM)}

1) $\mathrm{Al}, \mathrm{As}, \mathrm{Ca}, \mathrm{Cd}, \mathrm{Cr}, \mathrm{Cu}, \mathrm{Fe}, \mathrm{K}, \mathrm{Mg}, \mathrm{Mn}, \mathrm{Na}, \mathrm{Ni}, \mathrm{P}, \mathrm{Pb}, \mathrm{S} \& \mathrm{Zn}$ in seaweed moisture and in the sample of the surrounding waters were measured on an ICP-AES (Thermo Iris) according pretreatment SWV E-3404, measurement SWV E-1304 and conservation SWV E-3404 guide lines at the Chemical Biological Laboratory for Soil \& Water Research, Wageningen University, Wageningen (The Netherlands).

2) As, B, Ba, Cd, Co, Cr, Cu, La, Li, Mn, Mo, Ni, Pb, Sb, Se, Sn, \& V in seaweed moisture and in the sample of the surrounding waters were measured on an HR-ICP-MS (Thermo Element 2) according pretreatment SWV E-3404, measurement SWV E-1325 and conservation SWV E-3404 guide lines at the same laboratory.

\subsection{P Measurements}

Determination of P was performed on an HR-ICP-MS (Thermo Element 2) according pretreatment SWV E-3404, measurement SWV E-1325 and conservation SWV E-3404 guide lines at the same laboratory.

\subsection{Principle Method}

The basic principle of our method is based on the fluid mosaic membrane which surrounds a seaweed cell but also organelles. We call this the "seaweed battery" because by sampling at both sides of the fluid mosaic bilayer we can get an impression of the interior milieu of the seaweed cell. All concentrations of macroor micro-elements [HM]-indeed at each side of the membrane bilayer-can have distinctive concentration differences dependent on the transport mechanisms (active or passive), and in some way related to their function or seaweed bilayer composition.

\subsection{Calculations}

$$
\text { Accumulation Factor }[\mathrm{AF}]=\frac{\mathrm{HM} \text { in the seaweed moisture }}{\mathrm{HM} \text { in the oceanic water }}
$$

The accumulation factor represents the concentration of the heavy metal in the seaweed moisture compared with the concentration in the seawater. Some parameters affecting the performance of this parameter are: 1) the physiological state of the seaweed, 2) the age of the cells, 3) the availability of micronutrients during their growth and finally 4) the environmental conditions during uptake dependent on $\mathrm{pH}$, temperature, light intensity etcetera $=>$ see Discussion. To our awareness the "Accumulation factor" based on the described "seaweed battery" principle is new and applied for the first time.

\subsection{Statistics}

Data processing was performed in Excel and SPSS [11]. Correlation coefficients of the overall macro-elements $(n=8)$ with the surrounding seawater, correlation 
coefficients of the micro-elements $(\mathrm{n}=10)$ with the surrounding seawater, and correlation coefficients of the overall macro-elements and micro-elements (all elements, $\mathrm{n}=18$ ) with the surrounding seawater for four seaweed species were calculated using SPSS [11].

\section{Results}

\subsection{Information from the Accumulation Factor [AF]}

To our awareness the Accumulation Factor [AF] has for the first time been applied in heavy metal [HM] studies with seaweeds.

For the $[\mathrm{HM}]$ for all four seaweed-species the following general conclusions can be made based on the Accumulation Factor given in Figure 7.

1) The $[\mathrm{HM}]$ in the seaweed moisture is higher than in the surrounding seawater which directs to mechanism (s) of bio-accumulation.

2) Accumulation factor is varying per metallic cation. Overall trend for our four seaweeds and sampling locations for $\mathrm{HM}$ are: $\mathrm{Cu}$, Co: (5000 - 10,000 Accumulation Factor $[\mathrm{AF}]$ range; Ni \& Zn: 3000 - 5000 [AF] range; Cd: 2000 3000 [AF] range; Cr: 1000 - 2000 [AF] range; Al: 200 - 1000 [AF] range; $\mathrm{Mo}, \mathrm{Pb}$, Mg \& Fe: 0 - $200[\mathrm{AF}]$ range.

3) For the $\mathrm{HM} \mathrm{Pb}, \mathrm{Zn} \& \mathrm{Fe}$ these micro-elements could not be detected in the seawater, so in order to calculate the accumulation factor we had to use the threshold value of the oceanic water for the ICP technique used. The fact that these HM could not be detected in the oceanic water while their concentration in the seaweed moisture is rather high seems to support the view that seaweeds have a preference in their bio-accumulation mechanism for these three HM (see discussion).

4) In addition to observation 3). Zn falls with [AF] extremely in the extremely high range of 3000 - 5000 for all four seaweed-species. This again partly can be explained because this HM could not be detected in the seawater, and in order to calculate the $[\mathrm{AF}]$ we had to use the threshold value of the oceanic water for the ICP technique used.

5) In incidental cases, a certain seaweed has an extremely high AF for a certain specific $\mathrm{HM}$ like in case of Ulva lactuca its preference for $\mathrm{Ni}^{2+}$ with an [AF]-factor of $\approx 5200$ (see Figure 7).

From Table 1 and Table 2 we can see that "overall" for the macro-elements $\mathrm{Ca}, \mathrm{Fe}, \mathrm{K}, \mathrm{Mg}, \mathrm{Mn}, \mathrm{Na}, \mathrm{P} \& \mathrm{~S}$ in the moisture of the four seaweed species the concentration is lower in the seaweed species, or equals the concentration, in comparison to the surrounding sea water. For the $\mathrm{HM}(\mathrm{Al}, \mathrm{As}, \mathrm{Cd}, \mathrm{Co}, \mathrm{Cr}, \mathrm{Cu}$, $\mathrm{Mo}, \mathrm{Ni}, \mathrm{Pb} \& \mathrm{Zn}$ ) given in Table 1 the opposite is the case species and is the concentration "overall" higher in the seaweed species in comparison to the surrounding sea water.

\subsection{Correlation between Seaweed Moisture and Macro- and Micronutrients $(\approx \mathrm{HM})$ with Surrounding Seawater}

If we take the "overall" correlation coefficient for macro- and microelements 
Table 1. Mean concentrations of Heavy Metals (HM) measured with ICP-techniques in four different seaweed species and oceanic water at the sampling location which delivers the ratio = Accumulation Factor (AF). Notify that $\mathrm{Fe}^{2+}, \mathrm{Mg}^{2+} \& \mathrm{Mn}^{2+}$ are macro-elements expressed in $[\mathrm{mg} / \mathrm{l}]$ while the other HM are microelements expressed in $[\mu \mathrm{g} / \mathrm{l}]$. Individual results are given in [12] van Ginneken et al. 2018 (this volume).

\begin{tabular}{|c|c|c|c|c|c|c|c|c|c|c|c|c|c|}
\hline & & $\begin{array}{c}\mathrm{Fe}^{2+} \\
{[\mathrm{mg} / \mathrm{l}]}\end{array}$ & $\begin{array}{c}\mathrm{Mg}^{2+} \\
{[\mathrm{mg} / \mathrm{l}]}\end{array}$ & $\begin{array}{c}\mathrm{Mn}^{2+} \\
{[\mathrm{mg} / \mathrm{l}]}\end{array}$ & $\begin{array}{c}\mathrm{Cu}^{2+} \\
{[\mu \mathrm{g} / 1]}\end{array}$ & $\begin{array}{c}\mathrm{Al}^{3+} \\
{[\mu \mathrm{g} / \mathrm{l}]}\end{array}$ & $\begin{array}{c}\mathrm{Zn}^{2+} \\
{[\mu \mathrm{g} / \mathrm{l}]}\end{array}$ & $\begin{array}{c}\mathrm{Cd}^{2+} \\
{[\mu \mathrm{g} / \mathrm{l}]}\end{array}$ & $\begin{array}{c}\mathrm{Co}^{2+} \\
{[\mu \mathrm{g} / 1]}\end{array}$ & $\begin{array}{c}\mathrm{Cr}^{3+} \\
{[\mu \mathrm{g} / 1]}\end{array}$ & $\begin{array}{l}\mathrm{Mo}^{4+} \\
{[\mu \mathrm{g} / \mathrm{l}]}\end{array}$ & $\begin{array}{c}\mathrm{Ni}^{2+} \\
{[\mu \mathrm{g} / \mathrm{l}]}\end{array}$ & $\begin{array}{r}\mathrm{Pb}^{2+} \\
{[\mu \mathrm{g} / 1]}\end{array}$ \\
\hline U. lactuca & Mean & 2.74 & 1762.00 & 3.77 & 330.75 & 153.00 & 1232.25 & 2.39 & 13.88 & 18.65 & 14.33 & 157.50 & 1.26 \\
\hline \multirow[t]{3}{*}{$(\mathrm{n}=4)$} & SD & 0.40 & 47.85 & 0.16 & 74.29 & 20.99 & 236.99 & 0.34 & 0.33 & 0.90 & 1.00 & 9.68 & 1.66 \\
\hline & Oceanic & 0.09 & 1214.00 & 0.01 & 0.13 & 0.30 & 0.30 & 0.01 & 0.01 & 0.01 & 2.07 & 0.03 & 0.04 \\
\hline & Ratio & 30.39 & 1.45 & 376.75 & 2544.23 & 510.00 & 4107.50 & 199.17 & 1982.14 & 1865.00 & 6.92 & 5250.00 & 31.38 \\
\hline C. sertlatioides & Mean & 1.08 & 509.25 & 1.18 & 117.85 & 582.75 & 1169.50 & 5.72 & 6.99 & 14.50 & 6.99 & 129.75 & 2.45 \\
\hline \multirow[t]{3}{*}{$(\mathrm{n}=4)$} & SD & 0.04 & 9.03 & 0.03 & 13.23 & 175.55 & 361.52 & 0.47 & 0.21 & 0.39 & 4.61 & 5.32 & 1.53 \\
\hline & Oceanic & 0.09 & 1206.00 & 0.01 & 0.02 & 0.70 & 0.30 & 0.00 & 0.01 & 0.01 & 1.14 & 0.36 & 0.04 \\
\hline & Ratio & 11.94 & 0.42 & 118.25 & 5892.50 & 832.50 & 3898.33 & 2860.00 & 1397.50 & 1611.11 & 6.13 & 360.42 & 61.19 \\
\hline C. brachypus & Mean & 0.90 & 675.50 & 2.05 & 788.25 & 230.00 & 1136.00 & 4.43 & 22.13 & 20.23 & 8.54 & 295.25 & 1.33 \\
\hline \multirow[t]{3}{*}{$(\mathrm{n}=4)$} & SD & 0.14 & 4.12 & 0.07 & 69.21 & 46.45 & 146.50 & 0.22 & 0.22 & 1.25 & 0.35 & 9.36 & 0.95 \\
\hline & Oceanic & 0.09 & 361.00 & 0.01 & 0.10 & 1.00 & 0.30 & 0.02 & 0.01 & 0.05 & 2.49 & 0.16 & 0.04 \\
\hline & Ratio & 9.98 & 1.87 & 204.75 & 7882.50 & 230.00 & 3786.67 & 221.63 & 3687.50 & 396.57 & 3.43 & 1845.31 & 33.19 \\
\hline$U \cdot$ pinnatifida & Mean & 0.25 & 121.25 & 0.02 & 73.90 & 156.00 & 178.75 & 0.81 & 1.04 & 6.16 & 14.80 & 20.08 & 0.09 \\
\hline \multirow[t]{3}{*}{$(\mathrm{n}=4)$} & SD & 0.03 & 5.32 & 0.01 & 12.78 & 9.93 & 18.45 & 0.13 & 0.12 & 0.27 & 3.00 & 3.89 & 0.15 \\
\hline & Oceanic & 0.09 & 547.00 & 0.01 & 0.01 & 0.30 & 0.30 & 0.00 & 0.01 & 0.00 & 1.11 & 0.03 & 0.04 \\
\hline & Ratio & 2.73 & 0.22 & 2.05 & 7390.00 & 520.00 & 595.83 & 201.88 & 207.50 & 1540.63 & 13.33 & 669.17 & 2.31 \\
\hline
\end{tabular}

Table 2. Correlation coefficients of the overall macro-elements $(n=8)$ with the surrounding seawater, correlation coefficients of the micro-elements $(\mathrm{n}=10)$ with the surrounding seawater, and correlation coefficients of the overall macro-elements and micro-elements (all elements, $\mathrm{n}=18$ ) with the surrounding seawater for four seaweed species: Ulva lactuca, Caulerpa sertlatioides, Caulerpa cf. brachypus and Undaria pinnatifida. Individual results are given in [12] (this volume).

\begin{tabular}{|c|c|c|c|c|c|c|c|c|c|}
\hline \multirow{2}{*}{ Seaweed type } & \multicolumn{3}{|c|}{ Macro-elements } & \multicolumn{3}{|c|}{ Micro-elements } & \multicolumn{3}{|c|}{ All elements } \\
\hline & A & $\mathbf{R}^{2}$ & & A & $\mathbf{R}^{2}$ & & A & $\mathbf{R}^{2}$ & \\
\hline Ulva lactuca & 0.1677 & -0.3970 & $<$ sea & 17.372 & -0.3267 & $>$ sea & 0.1677 & -0.0520 & $<$ sea \\
\hline Caulerpa cf. brachypus & 0.4991 & 0.9756 & $<$ sea & 61.65 & -0.5406 & $>$ sea & 0.4991 & 0.9796 & $<$ sea \\
\hline Undaria pinnatifida & 0.1726 & 0.9990 & $<$ sea & 25.256 & -0.7211 & $>$ sea & 0.1726 & 0.9992 & $<$ sea \\
\hline \multicolumn{10}{|l|}{$\begin{array}{c}<\text { Seawater moisture elements } \\
\text { content lower than element } \\
\text { contents seawater }\end{array}$} \\
\hline
\end{tabular}


together, the bio-accumulation effect of seaweeds for [HM] is dominating and the determines the "all-over" correlation coefficient between the macro- and micro-elements in the moisture of the seaweeds in comparison to the surrounding sea water.

From Table 3 we can see that there is no perfect seaweed for which we can press suitable moisture out of its seaweed fronds to fulfill the limitation of human consumption or agriculture irrigation. All the moisture from the four seaweeds exceeded the limitations and, especially for the elements $\mathrm{K}, \mathrm{Mg}, \mathrm{Mn}, \mathrm{Na}$, P, S \& As. Only Undaria pinnatifida (Wakame), seems to be most suitable for agricultural irrigation because of the 17 measured micro- and macro-elements 11 of them were below the threshold for Agricultural irrigation [7]. For the in this study selected general research question if HM seaweed moisture exceeds the FAO directed thresholds for irrigation water this was for Wakame originating from the remote area West-Donegal, (Ireland) not the case for the following $\mathrm{HM}$ cations: $\mathrm{Cu}, \mathrm{Cd}, \mathrm{Co}, \mathrm{Cr}, \mathrm{Ni} \& \mathrm{~Pb}$; however this was not the case for the metallic cations As \& Mo [7]. The latter two HM cations might even have at this remote area of this planet a negative impact on the marine ecosystem.

Table 3. Elements and nutrients limitation of water for human consumption and agricultural irrigation [5] [7] and the micro- and macro element concentrations in the pressed moisture of Ulva lactuca (Sea lettuce), Caulerpa sertularioides, Caulerpa cf. brachypus and Undaria pinnatifida (Wakame). HC: ratio of mean measured micro-macro-element of the seaweed (mean) divided by the threshold for Human consumption (value below one (bold and underlined)) is suitable. Ai: ratio of mean measured micro-macro-element of the seaweed (mean) divided by the threshold for agricultural irrigation (value below one (bold and underlined)) is suitable.

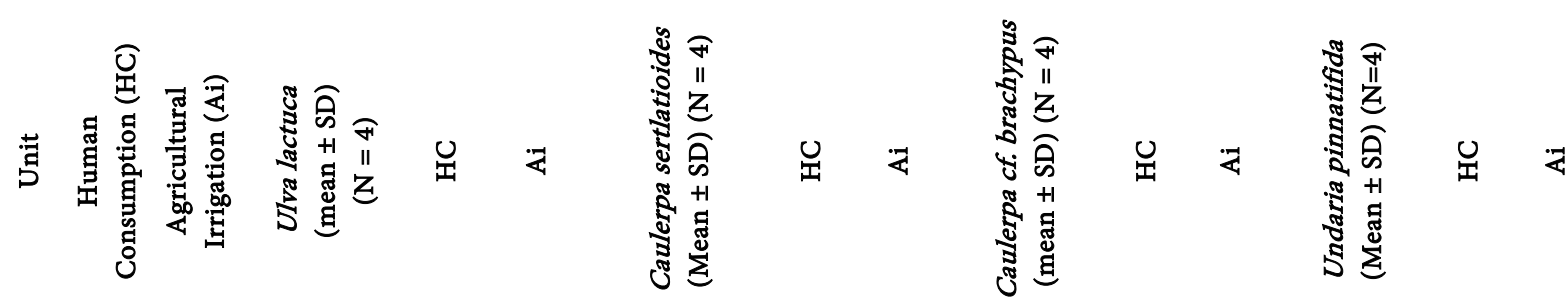

\begin{tabular}{|c|c|c|c|c|c|c|c|c|c|c|c|c|c|c|c|}
\hline $\mathrm{Al}$ & $\mathrm{g} / \mathrm{l}$ & 200 & 5000 & $122.4 \pm 20.99$ & 0.61 & 0.02 & $582.8 \pm 175.6$ & 2.9 & 0.12 & $184 \pm 46.45$ & 0.92 & 0.04 & $156.0 \pm 9.93$ & 0.78 & 0.03 \\
\hline $\mathrm{Ca}$ & $\mathrm{mg} / \mathrm{l}$ & 100 & 400 & $442.0 \pm 20.70$ & 4.42 & 1.1 & $530.0 \pm 25.5$ & 5.3 & 32 & $52 \pm 3.27$ & 3.52 & 0.88 & $110.5 \pm 1.00$ & 1.11 & 0.28 \\
\hline $\mathrm{Cu}$ & $\mathrm{ug} / \mathrm{l}$ & 100 & 200 & $264.6 \pm 74.29$ & 2.65 & 1.3 & $117.9 \pm 13.2$ & 1.2 & 0.59 & $630.6 \pm 69.21$ & 6.30 & 3.15 & $73.9 \pm 12.78$ & 0.74 & 0.37 \\
\hline $\mathrm{Fe}$ & $\mathrm{mg} / \mathrm{l}$ & 0.2 & 5 & $2.188 \pm 0.40$ & 10.9 & 0.4 & $1.08 \pm 0.04$ & 5.4 & 0.22 & $0.718 \pm 0.14$ & 3.6 & 0.14 & $0.2 \pm 0.03$ & 0.002 & 0.04 \\
\hline $\mathrm{K}$ & $\mathrm{mg} / \mathrm{l}$ & 12 & 2 & $964.0 \pm 34.29$ & 80.3 & 482 & $481.0 \pm 5.35$ & 40 & 11 & $540.4 \pm 4.12$ & 45 & 270 & $121.3 \pm 5.32$ & 10.1 & 60.7 \\
\hline $\mathrm{Mg}$ & $\mathrm{mg} / \mathrm{l}$ & 50 & 60 & $1409.6 \pm 47.85$ & 28.2 & 23.5 & $509.3 \pm 9.03$ & 10.2 & 0.49 & $620.8 \pm 12.25$ & 12.4 & 10.3 & $327.5 \pm 8.66$ & 6 & 5.46 \\
\hline $\mathrm{Mn}$ & $\mathrm{mg} / \mathrm{l}$ & 0.05 & 0.2 & $3.014 \pm 0.16$ & 60.3 & 15.1 & $1.2 \pm 0.03$ & 24 & 6.0 & $1.638 \pm 0.07$ & 32.8 & 8.19 & $0.02 \pm 0.01$ & 0.40 & 0.10 \\
\hline $\mathrm{Na}$ & $\mathrm{mg} / \mathrm{l}$ & 175 & 920 & $1090.4 \pm 26.26$ & 6.2 & 1.19 & $6238.8 \pm 92.33$ & 35.7 & 6.8 & $5342.8 \pm 75.1$ & 30.5 & 5.81 & $3147.0 \pm 32.3$ & 18.0 & 3.42 \\
\hline$S$ & $\mathrm{mg} / \mathrm{l}$ & 150 & 320 & 87.55 & 29.3 & 13.7 & $581.8 \pm 155.56$ & 3.9 & 8 & 79.4 & 7.3 & 3.44 & 7.19 & 2.30 & 1.08 \\
\hline $\mathrm{Zn}$ & $\mathrm{ug} / \mathrm{l}$ & 100 & 2000 & 985.8 & 9.9 & 0.49 & 11 & 11.7 & 0.58 & .5 & 9.1 & 45 & .45 & 79 & .09 \\
\hline As & $\mathrm{ug} / \mathrm{l}$ & 50 & 100 & $96.4 \pm 4.65$ & 1.9 & 0.96 & $474.5 \pm 6.35$ & 9.5 & 4.8 & $228.4 \pm 6.35$ & 4.6 & 2.28 & $164.8 \pm 10.97$ & 3.30 & 1.65 \\
\hline $\mathrm{Cd}$ & $\mathrm{ug} / \mathrm{l}$ & 5 & 10 & $1.912 \pm 0.34$ & 0.4 & 0.19 & $5.7 \pm 0.47$ & 1.1 & 0.57 & $3.55 \pm 0.22$ & 0.71 & 0.36 & $0.70 \pm 0.06$ & 0.14 & 0.07 \\
\hline Co & $\mathrm{ug} / \mathrm{l}$ & 5 & 50 & $11.1 \pm 0.33$ & 2.2 & 0.22 & $7.0 \pm 0.21$ & 1.4 & 0.14 & $17.7 \pm 0.22$ & 3.54 & 0.35 & $1.0 \pm 0.12$ & 0.20 & 0.02 \\
\hline $\mathrm{Cr}$ & $\mathrm{ug} / \mathrm{l}$ & 50 & 100 & $14.92 \pm 0.90$ & 0.3 & 0.15 & $14.5 \pm 0.39$ & 0.3 & 0.15 & $16.18 \pm 1.25$ & 0.32 & 0.16 & $6.2 \pm 0.27$ & 0.12 & 0.06 \\
\hline Mo & $\mathrm{ug} / \mathrm{l}$ & 5 & 10 & $11.46 \pm 1.00$ & 2.3 & 1.15 & $7.0 \pm 4.61$ & 1.4 & 0.70 & $6.832 \pm 0.35$ & 1.37 & 0.68 & $14.8 \pm 3.00$ & 2.96 & 1.48 \\
\hline $\mathrm{Ni}$ & $\mathrm{ug} / \mathrm{l}$ & 50 & 200 & $126.0 \pm 9.68$ & 2.5 & 0.63 & $129.8 \pm 5.32$ & 2.6 & 0.65 & $236.2 \pm 9.36$ & 4.72 & 1.18 & $20.1 \pm 3.89$ & 0.40 & 0.10 \\
\hline $\mathrm{Pb}$ & $\mathrm{ug} / \mathrm{l}$ & 50 & 5000 & $1.004 \pm 1.66$ & 0.02 & 0.0002 & $2.4 \pm 1.53$ & 0.05 & 0.0005 & $1.062 \pm 0.95$ & 0.02 & 0.0002 & $0.10 \pm 0.15$ & 0.002 & .00002 \\
\hline
\end{tabular}




\section{Discussion}

\subsection{Seaweeds and the Mechanism of HM Accumulation Explained in General Terms}

In this study, at first sight a detrimental property of seaweeds that can accumulate HM in their moisture (far above the level of the surrounding seawater) was confirmed by other studies with seaweeds, some of which are mentioned below. But intensifying the reasoning why living seaweeds accumulate HM in their biomass and metabolism the following explanation can be given. In general terms, this specific property of seaweeds to accumulate HM can be ascribed to the effect that HM can be classified as essential mineral nutrients that for both macro- and micro-elements are essential in an aquatic environment were live seaweeds. In general terms, this virginal aquatic not by anthropogenic influences often tropical seas or oceans at great depth with lack of light (in quantity and quality) can be characterized by low levels of macronutrients ( $\mathrm{N} \& \mathrm{P}$ ) (in $\mathrm{mg} / \mathrm{l}$ ), micronutrients like $\mathrm{Fe}, \mathrm{Cu}, \mathbf{M g} \& \mathrm{Zn}$ (also in $\mathrm{mg} / \mathrm{l}$; see Table 1), including scarce amounts of minerals often ions or metallic cations (HM) (in $\mu$ g/l; see Table 1). Seaweed species which have adapted themselves to live under such harsh conditions have developed the trait of sequestering and store any surplus of nutrients ( $\mathrm{N} \& \mathrm{P}$ ), minerals-often metallic cations-at these scarce moments these inorganic compounds are available. We hypothesize-in trying to explain the issue of HM accumulation by seaweeds grow-that this sequestering and accumulation mechanism was a positive trait for a certain seaweed species-and during course of evolution selection mechanism-was probably favorable for seaweed species which were better genetically provided for traits which can be characterized by sequestering and storage abilities [13]. Perhaps for this reason, the nowadays living seaweeds can absorb and store large quantities of these nutrients \& minerals for later use. Concentrations of some mineral nutrients in aquatic plants casu quo seaweeds, most notably micronutrients such as $\mathrm{Fe}$ and $\mathrm{Cu}$, can exceed the level in the surrounding water by 1000 to $1,000,000$ times [14]. Concentrations of HM and macro-elements in seaweeds are regulated to a large extent by metabolic requirements for essential macronutrients and micronutrients [15].

\subsection{Reliable Biomonitoring Systems for HM}

1) With respect to a reliable practical bio-monitoring system, recently it has been verified in two recent studies that seaweeds growing at the Antarctic (for which it was assumed it was a virginal nearly unpolluted environment stripped of any anthropogenic contamination with $\mathrm{HM}$ ) were contaminated with HM like mercury $(\mathbf{H g})$, lead $(\mathbf{P b})$ and cadmium (Cd) [9]. So this proves that even in expected clean Antartic polar areas, far away from any anthropogenic influences, seaweeds like Laminaria saccharina, Fucus distichus and Desmarestia aculeata can act as bio-monitoring system for aquatic environmental pollution with HM [16]. 
2) The fact that seaweeds can have a function as a bio-monitoring system to estimate the accumulation of HM discharged in the oceanic-and thus can serve as an environmental bio-monitoring system-implies that there is a close relation to the oceanic $[\mathrm{HM}]$ and the $[\mathrm{HM}]$ in living seaweed-biomass. Because HM are available to seaweeds only from the dissolved phase, concentrations in these organisms may only reflect the bioavailable levels of a HM in the solute aquatic phase [15].

3) In addition, several studies have indicated that metal concentrations in Enteromorpha sp. directly reflect metal concentration in the surrounding water [15]. This is an important observation because it means that the HM load ( $\approx$ contamination) of seaweed moisture is on one hand (varying to some extent between metallic cation, seaweed species and concentration of the metallic cation in the corresponding surrounding oceanic water, see Table 1). However, in general terms spoken: all $[\mathrm{HM}]$ cations are directly dependent on the contamination of the oceanic environment.

4) The Moroccan phosphate industry releases large amounts of heavy metals in the Atlantic Ocean of which is major waste is called phosphor-gypsum. From the yearly amount of phosphor-gypsum produced by the Moroccan industry and the element concentrations in phosphor-gypsum, it has been possible to estimate a yearly flux of heavy metals introduced in the Atlantic Ocean. Seaweeds were used as bio-accumulator materials of heavy metals in the marine environment, in the region of "Jorf Lasfar", in order to significantly reveal the signal of the heavy metal pollution. Ulva lactuca (Linnaeus) was selected to assess heavy metal pollution around the waste release point. Accumulation factors were determined for 47 elements in $U$. lactuca, by comparing mean concentrations obtained in algae collected in non-polluted sites (background sites) and an average sea water concentration given in the literature. The ratio between the concentration in $U$. lactuca, collected in a polluted site to the background concentration in $U$. lactuca, was determined, giving an estimate of the pollution factor for the same elements by the phosphate industry. The decrease of the pollution due to the dilution in the sea water was observed as far as $6 \mathrm{~km}$ southward of the release point [17].

\subsection{Bio-Sorption of Heavy Metals by Death Seaweed to Clean the Aquatic Environment}

"Bio-sorption" - often confused by many authors by the term "Bio-accumulation"-is the removal of HM from an aqueous solution by passive binding to non-living seaweed biomass [18]. Bio-sorption by death seaweed biomass is considered a potential instrument for the removal of metals from waste solutions and for precious metals recovery, an alternative to the conventional processes, such as those based on ion exchange, or adsorption on activated carbon [19]. Accumulation of HM by seaweeds had been studied extensively for bio-monitoring or bioremediation purposes. Having the advantages of low cost raw material, big adsorbing capacity, no secondary pollution, etcetera, seaweeds may be used to treat water 
bodies or harbors polluted by industrial water containing HM. An example of such successful operation in practice, was the cleaning of the harbor of Hong-Kong from HM by death seaweed biomass [20]. Another example is the cleaning of Tolo harbor in Zaire at an almost landlocked sea called Lake Mai-Ndombe at the river Lukenie \pm 1000 - $1200 \mathrm{~km}$ East from the Atlantic Ocean nearly in the middle of the continent at the "Grande Dépression Centrale" [21]. This example exemplifies the possibilities seaweed (dead or alive) offers the underdeveloped world to clean industrial areas or waters from heavy metal pollution.

\subsection{Bio-Accumulation in Living Seaweeds}

Accumulation of HM by living seaweeds has been shown to occur in two phases. The first is a rapid surface reaction (reviewed in [18]). These are mechanisms completely independent from the metabolism of the biomass. In the latter case physical-chemical interaction occurs between the toxic metal and the surface polysaccharides of the biomass, ion-exchange, complexation and adsorption take place, and the phenomenon is not metabolism dependent and independent of the biomass [22]. The second phase is characterized by a much slower HM uptake over a period of hours [18] [23]. In the latter case, metabolically mediated processes with an elapsed time needed for the transport of the toxic cation over the cell wall into the cell have to take place (Figure 8). Some parameters affecting the performance of living bio-sorbents are: 1) the physiological state of the seaweed, 2) the age of the cells, 3) the availability of micronutrients during their growth and finally 4) the environmental conditions during uptake like $\mathrm{pH}$, temperature, light intensity etcetera [18]. Figure 9 illustrates the potential routes of uptake and efflux for potentially toxic metal, but also the binding and blocking mechanisms which are assumed to operate like in bacteria but is an unexploited research area.

It can be considered as an optimistic "signal" from this study that the seaweed Undaria pinnatifida (Wakame), collected at the "to intermediate anthropogenic influences" exposed area West-Donegal, Ireland was according to the FAO standards for irrigation and drainage [7] suitable for agricultural irrigation for 11 of the 17 measured macro- and micro-elements (see Table 3). At first literature data have to give us at first the information how clean $(\approx$ not polluted with $\mathrm{HM})$ the oceanic waters for the Sahara desert $\left(10^{\circ} \mathrm{N}\right.$ to $\left.30^{\circ} \mathrm{N}\right)$ are. This should be followed by extensive and reliable measurements of ocean water along with seaweed juice (as performed in this experiment) at a new experimental field station in the Sahara. In Europe already unexpected "Sahara Dust" containing HM has been reported in France at the Seine River basin. Total aerosol fallout of HM at the Seine River basin (France), also includes dust that originates either from local sources, i.e. erosion from crop fields in the basin (52\% of the Seine basin) [25], anthropogenic impact of $\mathrm{Cu}, \mathrm{Pb}$ and $\mathrm{Zn}$, possibly originated from municipal sewage (reviewed [15]) or from external sources as far as "Sahara Dust" as discussed in detail by [26]. Several authors indicate the existence of this observation called "Sahara Dust", also in potency could contaminate the local 


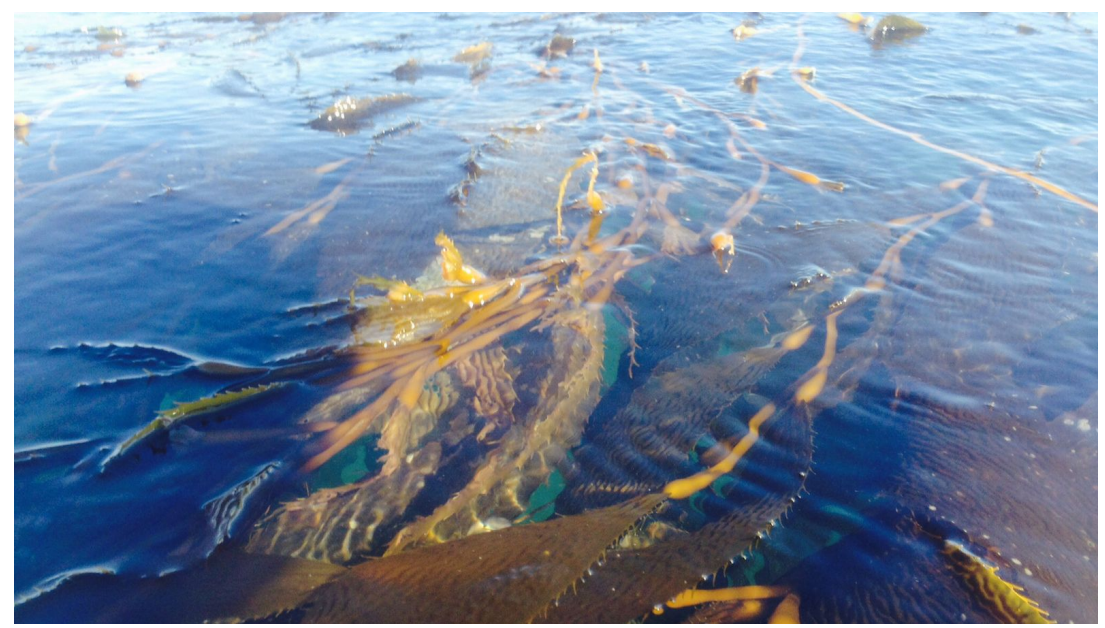

Figure 8. Cultivation of seaweed species at low-tech level at the remote areas of our planet in order to irrigate the Sahara with the moisture out of seaweeds.

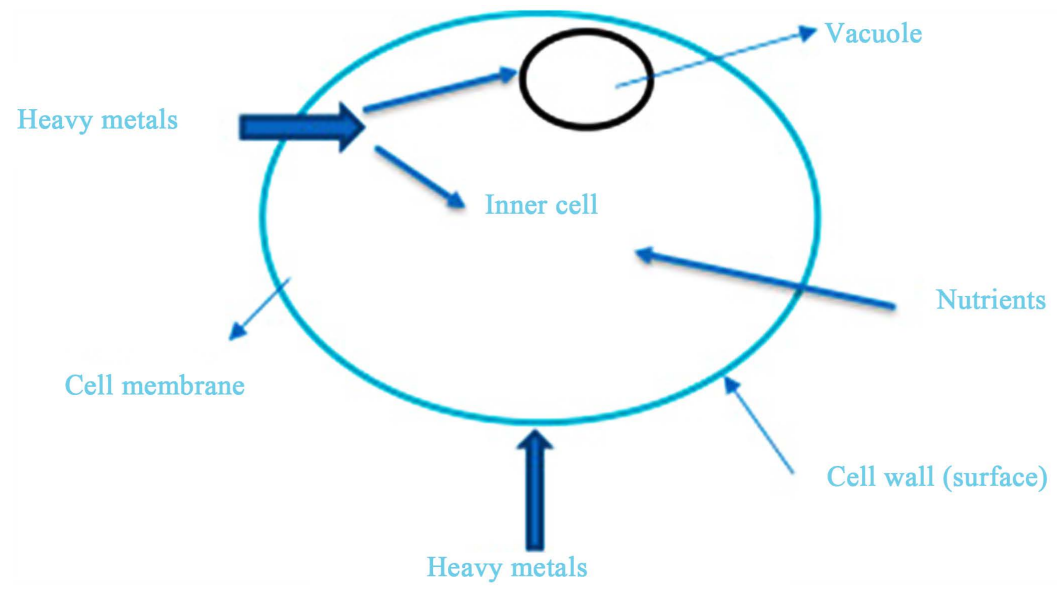

Figure 9. It is assumed bio-accumulation of heavy metals in seaweeds is following similar mechanisms as described for bacteria for the remediation of heavy metal pollution [24].

oceanic water in the vicinity of the Sahara. [27] reported that during the "Harmattan Season" in West Africa (December-March), several million tons of wind-blown dust from the Sahara are deposited in the coastal areas. [28] determined from sediment trap samples collected between 1 December 1986 and 30 April 1987 at 1020 and $4120 \mathrm{~m}$ below the ocean surface particulate fluxes of aluminum (Al), cadmium (Cd), cobalt $(\mathrm{Co})$, copper $(\mathrm{Cu})$, iron $(\mathrm{Fe})$, manganese $(\mathrm{Mn})$, nickel $(\mathrm{Ni})$, phosphorus $(\mathrm{P})$, lead $(\mathrm{Pb})$, vanadium $(\mathrm{V})$ and zinc $(\mathrm{Zn})$ in the northeast subtropical Atlantic Ocean. The fluxes of most elements (except Cd and $\mathbf{P}$ ) show small variations between the different layers and are closely associated with the vertical transport of aluminum. Elemental composition and flux rates suggest that aerosol loadings from northeast trade winds (also called "Sahara dust") are the major contributor of these elements to depositing material. More specific for the effect of Sahara dust on the oceanic environment, [29] collected water samples (6 m depth) at several oceanic locations in the open Atlantic Ocean and in the Brazilian and northwest European shelf areas during three 
transects between $23^{\circ} \mathrm{S}$ and $59^{\circ} \mathrm{N}$ in October/November 1980, August/September 1981, and March/April 1982. The open Atlantic cadmium (Cd), copper ( $\mathbf{C u}$ ), and nickel $(\mathrm{Ni})$ concentrations increase towards higher latitudes with averages $\left(\mathrm{nmol} \cdot \mathrm{kg}^{-1} \pm 1 \mathrm{~s}\right)$ and ranges of 0.002 to $0.10(0.040 \pm 0.026) \mathrm{Cd} ; 0.86 \pm 0.34$ $(1.28 \pm 0.26) \mathrm{Cu}$; and $1.88 \pm 0.66(3.40 \pm 0.61) \mathrm{Ni}$ in the regions $7^{\circ} \mathrm{S}$ to $35^{\circ} \mathrm{N}$ $\left(\approx\right.$ Sahara $=>$ Morocco) and $35^{\circ}$ to $59^{\circ} \mathrm{N}$ (Eastern of Ireland), respectively. These elevations are probably the result of the biogeochemical cycles of these elements and of the hydrographical regimes in those regions. The manganese and aluminum distributions show a different geographical pattern with maximum concentrations in the region between around $10^{\circ} \mathrm{N}$ to $30^{\circ} \mathrm{N}(\approx$ oceanic area of the Sahara), which probably originate from Aeolian input (also called "Sahara dust"). The mean values are $2.74 \pm 1.01 \mathrm{Mn}$ and $25.4 \pm 7.3 \mathrm{Al}$ (nanomol. $\mathrm{kg}^{-1}$ ) in comparison to "background" values of around 1.0 $\mathrm{Mn}$ and $15 \mathrm{Al}$, respectively. With respect to the issue if the oceanic water close to the Sahara $\left(10^{\circ} \mathrm{N}\right.$ to $\left.30^{\circ} \mathrm{N}\right)$, is contaminated can make the following important conclusion. The coastal waters close to the Sahara $\left(10^{\circ} \mathrm{N}\right.$ to $\left.30^{\circ} \mathrm{N}\right)$ are contaminated to some extent by "Sahara Dust", but also by sources of anthropogenic origin like these associated with fossil fuel, and coal combustion, industrial effluent, solid waste disposal, fertilizers, mining and metal processing [27]. So in respect to the major initial question of this research: if we could use the Sahara oceanic water to grow large seaweed plantation which will deliver by mechanical pressure brackish seaweed moisture and finally fresh irrigation water (using energy of the fermented "press-cake" [30] to create new agricultural area in this Sahara desert), the observation and major conclusion of [29] that the waters close to the Sahara $\left(10^{\circ} \mathrm{N}\right.$ to $\left.30^{\circ} \mathrm{N}\right)$ and further at the northwest European shelf area are 3 - 5 times less contaminated in comparison to waters of the central North Sea is very positive and optimistic. Regarding the observations made in this study for Undaria pinnatifida (Wakame), collected at the North Sea in an "to intermediate anthropogenic influences" exposed area West-Donegal, Ireland was according to the FAO standards for irrigation and drainage [7] was according to the FAO standards for irrigation and drainage [7] suitable for agricultural irrigation for 11 of the 17 measured macro- and micro-elements. This is an optimistic signal in order to irrigate the Sahara desert with the moisture out of seaweeds after a further biochemical desalination of the remaining $8 \%$ [12] with conventional techniques. According to this model, Africa could in theory become the food-producing continent in the world based on only the following economic input factors which are currently unused: maximum solar irradiation, ocean water which is eutrophic and contains the fertilizers N \& P in high concentrations [31], seaweeds, and cheap land (desert) and labor (Figure 8). Our further elaborations will be published very soon.

\section{References}

[1] Duffus, J.H. (2002) "HM"-A Meaningless Term. Pure and Applied Chemistry, 74, 793-807. https://doi.org/10.1351/pac200274050793 
[2] EC (European Commission) Directive: 76/464/EEC (1976) Water Pollution by Discharges of certain Dangerous Substances.

[3] Luoma, S.N., Bryan, G.W. and Langston, W.J. (1982) Scavenging of HM from Particulates by Brown Seaweed. Marine Pollution Bulletin, 13, 394-396.

https://doi.org/10.1016/0025-326X(82)90116-3

[4] FAO/WHO (2001) FAO/WHO Expert Consultation on Human Vitamins and Mineral Requirements. Report of a Joint FAO/WHO Expert Consultation, Bangkok, Thailand, $290 \mathrm{pp}$.

[5] EEC (1980) Council Directive 80/778/EEC of 15 July 1980 Relating to the Quality of Water Intended for Human Consumption. Official Journal of the European Communities, No. L229, 11.

[6] US EPA (1998) National Recommended Water Quality Criteria. Federal Register, 63, 68354-68364.

[7] Ayers, R.S. and Westcot, D.W. (1994) Water Quality for Irrigation. FAO Irrigation and Drainage Paper 29.

[8] Alvarez M.M. (2001) "How Much Is Too Much"? Teaching Measurements and Solution Concentration through Bioaccumulation and Levels of Toxicity. "Yale National Initiave".

[9] Koeman, R.P.T. and van den Hoek, C. (1980) The Taxonomy of Ulva (Chlorophyceae) in the Netherlands. British Phycological Journal, 16, 9-53.

https://doi.org/10.1080/00071618100650031

[10] Dhargalkar, V.K. and Kavlekar, D. (2004) Seaweeds-A Field Manual. 1st Edition, National Institute of Oceanography, Dona Paula, Goa.

[11] Field, A. (2005) Discovering Statistics Using SPSS. Sage Publications Ltd., Thousand Oaks, 779 p.

[12] van Ginneken, V. (2018) Some Mechanism Seaweeds Employ to Cope with Salinity Stress in the Harsh Euhaline Oceanic Environment. American Journal of Plant Sciences, 9, 1191-1211. https://doi.org/10.4236/ajps.2018.96089

[13] Hurd, C.L., Harrison, P.J., Bischof, K. and Lobban, C.S. (2014) Seaweed Ecology and Physiology. 2nd Edition, Cambridge University Press, Cambridge, 551 p. https://doi.org/10.1017/CBO9781139192637

[14] Huebert, D. (2011) “Water Plants", a Basic Introduction to the Physiology and Ecology of Aquatic Plants. http://www.hallman.org/plant/huebert.html

[15] Žbikowski, R., Szefer, P. and Latala, A. (2006) Distribution and Relationships between Selected Chemical Elements in Green Alga Enteromorpha sp. from the Southern Baltic. Environmental Pollution, 143, 435-448. https://doi.org/10.1016/j.envpol.2005.12.007

[16] Pongratz, R. and Heumann, K. (1998) Production of Methylated Mercury and Lead by Polar Seaweeds-A Significant Natural Source for Atmospheric HM in Clean Room Compartments. Chemosphere, 36, 1935-1946. https://doi.org/10.1016/S0045-6535(97)10078-9

[17] Gaudry, A., Zeroual, S., Gaie-Levrel, F., Moskura, M., Boujrhal, F.-Z., Cherkaoui, E., Moursli, R., Guessous, A., Mouradi, A., Givernaud, T. and Delmas, R. (2007) Heavy Metals Pollution of the Atlantic Marine Environment by the Moroccan Phosphate Industry as Observed through Their Bioaccumulation in Ulva lactuca. Water, Air, and Soil Pollution, 178, 267-285.

[18] Murphy, V. (2007) An Investigation into the Mechanisms of HM Binding by Selected Seaweed Species. PhD Thesis, Waterford Institute of Technology, $329 \mathrm{p}$. 
[19] Veglio, F. and Beolichini, F. (1997) Removal of Metals by Bio-Sorption: A Review. Hydrometallurgy, 44, 301-316.

[20] Ho, Y. (1987) Metals in Nineteen Intertidal Seaweeds in Hong Kong Waters. Marine Pollution Bulletin, 18, 564-566. https://doi.org/10.1016/0025-326X(87)90542-X

[21] Wong, M.H., Kwok, T.T. and Ho, K.C. (1982) Heavy Metals in Ulva lactuca Collected within Tolo Harbor, an Almost Landlocked Sea. Hydrobiological Bulletin, 16, 223-230. https://doi.org/10.1007/BF02255376

[22] Antunes, W.M., Luna, A.S., Henriques, C.A. and da Costa, A.C. (2003) An Evaluation of Copper Bio-Sorption by a Brown Seaweed under Optimized Conditions. Electronic Journal of Biotechnology, 6, 174-184.

[23] Crist, R.H., Oberholser, K., Mcgarrity, J., Crist, D.R., Johnson, J.K. and Brittsan, J.M. (1992) Interaction of Metals and Protons with Seaweeds. Marine-Seaweeds, with Emphasis on Lead and Aluminium. Environmental Science \& Technology, 26, 496-502. https://doi.org/10.1021/es00027a007

[24] Bwapwa, J.K., Jaiyeola, A.T. and Chetty, R. (2017) Bioremediation of Acid Mine Drainage using Algae Strains: A Review. South African Journal of Chemical Engineering, 24, 62-70. https://doi.org/10.1016/j.sajce.2017.06.005

[25] Meybeck, M., Lestel, L., Bonté, P., Moilleron, R., Colin, J.-L., Rousselot, O., Hervé, D., de Pontevès, G.C. and Thévenot, D.R. (2007) Historical Perspective of HM Contamination (Cd, Cr, Cu, Hg, Pb, Zn) in the Seine River Basin (France) Following a DPSIR Approach (1950-2005). Science of the Total Environment, 375, 204-231. https://doi.org/10.1016/j.scitotenv.2006.12.017

[26] Thévenot, D.-R., Moilleron, R., Lestel, L., Gromaire, M.-C., Rocher, V., Cambier, P., et al. (2007) Critical Budget of Metal Sources and Pathways in the Seine River Basin (1994-2003) for $\mathrm{Cd}, \mathrm{Cr}, \mathrm{Cu}, \mathrm{Hg}, \mathrm{Ni}, \mathrm{Pb}$ and $\mathrm{Zn}$. Science of the Total Environment, 375, 180-203. https://doi.org/10.1016/j.scitotenv.2006.12.008

[27] Olade, M.A. (1987) HM Pollution and the Need for Monitoring: Illustrated for Developing Countries in West Africa. In: Hutchinson, T.C. and Meema, K.M., Eds., Lead, Mercury, Cadmium, and Arsenic in the Environment, John Wiley \& Sons Ltd., Hoboken, Chapter 20, 335-341.

[28] Kremling, K. and Streu, P. (1993) Saharan Dust Influenced Trace Element Fluxes in Deep North Atlantic Subtropical Waters. Deep Sea Research Part I: Oceanographic Research Papers, 40, 1155-1168. https://doi.org/10.1016/0967-0637(93)90131-L

[29] Kremling, K. (1985) The Distribution of Cadmium, Copper, Nickel, Manganese, and Aluminum in Surface Water of the Open Atlantic and European Shelf Area. Deep Sea Research Part A: Oceanographic Research Papers, 32, 531-555. https://doi.org/10.1016/0198-0149(85)90043-3

[30] Yokoyama, S., Jonouchi, K. and Imou, K. (2007) Energy Production from Marine Biomass: Fuel Cell Power Generation Driven by Methane Produced from Seaweed. World Academy of Science, Engineering and Technology, 28, 320-323.

[31] van Ginneken, V. (2017) The Photosynthetic System of the Seaweeds: The Seaweed Paradox Asian. Journal of Science and Technology, 8, 6567-6571. 